\title{
BRUNO EDGAR IRGANG (1941-2006)
}

No dia 21 de outubro de 2006 faleceu, subitamente, aos 65 anos de idade, o botânico e professor aposentado da UFRGS Bruno Edgar Irgang, em conseqüência de choque cardiogênico e de infarto agudo do miocárdio inferior.

Nascido em 5 de março de 1941, em Três Passos - RS, Bruno descendia de uma família de russos-alemães. Na juventude, estudou em Três Passos, Panambi e Porto Alegre. Nesta cidade, trabalhou como cobrador, metalúrgico e auxiliar de escritório, a fim de estudar e sustentar-se. Ingressou no Curso de História Natural da UFRGS em 1964, licenciando-se em 1967.

Seu interesse pela área de Botânica foi despertado pelos professores da disciplina, nascendo desta relação uma grande amizade e oportunidades de progresso acadêmico. Quando obteve bolsa de estágio no Setor de Botânica, demitiu-se do emprego para assumir o cargo e iniciar uma exitosa carreira científica.

Ingressou no Departamento de Botânica da UFRGS em 1969, como Auxiliar de Ensino. Em 1975 obteve o título de Mestre em Botânica com o trabalho "O gênero Eryngium no RS" e, posteriormente, o título de Doutor, com a tese "Comunidades de Macrófitas Aquáticas da Planície Costeira do RS".

Nunca exerceu cargos administrativos na universidade, dedicando-se aos cursos de graduação, pós-graduação e pesquisa: "meu trabalho é na sala de aula e no campo", dizia cada vez que lhe formulavam um convite.

Gozava de grande simpatia entre os alunos, com os quais mantinha uma sólida e duradoura relação de amizade. Dele afirmavam: "O prof. Bruno é autêntico, tem conhecimento, é hones- to, de excelente didática e humilde". Incontáveis vezes foi homenageado nas colações de grau.

Sua produção científica destaca-se pelos inúmeros trabalhos publicados individualmente ou em co-autoria com colegas brasileiros e estrangeiros, principalmente na área de Taxonomia de Angiospermas. Foi também autor ou co-autor de livros nas áreas de Botânica Sistemática, Fitogeografia, Plantas Medicinais, Plantas Arbóreas e Fitossociologia.

Extensionista nato, o prof. Bruno não se furtava em sair do âmbito da universidade e ir às comunidades urbanas e rurais, para levar conhecimento e também aprender.

A preservação ambiental era sua constante preocupação político-ideológica e seus trabalhos visavam esse objetivo. Participou da elaboração de projetos e da implantação de 10 áreas de reserva da flora e fauna rio-grandense. Realizou e propôs programas de valorização do meio ambiente, junto às prefeituras municipais, instituições de pesquisa, escolas e associações de classe, sempre voltado ao conhecimento e valorização da flora brasileira e sul-rio-grandense, bem como à formulação de políticas de educação ambiental e de preservação de qualquer fragmento do patrimônio natural. Mais do que um dever, a verdadeira ação comunitária era para ele motivo de muita satisfação pessoal.

Sua partida deixa muita saudade aos familiares: Rosana, Jane e filhos Alexandre, Gustavo, Rafael, Daniela, Sabrina. Para a comunidade botânica, além da perda irreparável, fica seu exemplo de vida, como professor, pesquisador e cidadão dedicado às questões ambientais.

Adelino Alvarez Filho 